Serhii Yefremov: Epitome of the Ukrainian Revolution

Author(s): Maxim Tarnawsky

Source: Kyiv-Mohyla Humanities Journal 4 (2017): 1-10

Published by: National University of Kyiv-Mohyla Academy

http://kmhj.ukma.edu.ua/ 


\title{
Serhii Yefremov: Epitome of the Ukrainian Revolution
}

\author{
Maxim Tarnawsky \\ University of Toronto, \\ Department of Slavic Languages and Literatures
}

\begin{abstract}
Yefremov's personal characteristics exemplify the characteristic features of the Ukrainian Revolution. He was an argumentative, pugnacious man, and the revolution was characterized by infighting. He was an institution builder, and that's a key element of the Ukrainian Revolution. He was ideologically an advocate of Ukrainian identity (sooner than social rights or state building) and that too was a feature of the Ukrainian Revolution. His diaries and ego writing offer a variety of evidence of these aspects of his personality.
\end{abstract}

Key Words: Serhii Yefremov, Academy of Sciences, diary, memoirs, Ukrainian Revolution.

Serhii Yefremov was one of the major figures of Ukrainian political and cultural life in the period before, during, and after the establishment of Ukrainian statehood in 1917-1921. If nothing else, his role as the deputy head of the Central Rada secures him in this pantheon. But his role was much larger than that of a government functionary. He was one of the key individuals whose journalistic and political activities led to the establishment of a Ukrainian state and he was one of the important voices shaping the policies of the Ukrainian state. In all of his activities, he was guided by a particular set of cultural and political ideas, which were an outgrowth of his particular understanding of the challenges facing the Ukrainian nation and its culture. In this he serves, to some extent, as an exemplary figure of the spirit of the times that led to Ukrainian statehood and to the problems that led to its demise. This exemplary role continued after the eventual Bolshevik victory and characterized his life and pursuits until his arrest and eventual death. And beyond even that, Yefremov, through his journalism, his memoirs and his diaries, is certainly one of the most extensive chroniclers of this period in Ukrainian history. He deserves our attention on two accounts: as a contributor to and as the epitome of the Ukrainian Revolution. In this essay, I shall concentrate on the latter point using mostly his autobiographical writing as a source and specifically focusing on three characteristic features.

In the spirit of full disclosure, I must also add that for me, personally, Yefremov is a small blot on my conscience. In my recent monograph on Ivan Nechui-Levytskyi, I needed a scapegoat, someone to blame for the traditional misreading of Nechui that I aimed to correct, and Yefremov fit the bill. Actually, he fit the bill very well, and he really was responsible for the skewed image of Nechui, but this one matter does not make him a scoundrel or a malicious liar. So by examining his person and his accomplishments in a wider context I hope to straighten whatever small dents I may have put in his reputation. And yet, the relationship between Yefremov and Nechui does highlight a very important quality of the younger man: he was a very headstrong and 
self-confident man who was never shy in expressing an opinion and was certainly quick to criticize others. His diaries and memoirs exhibit this quality in great detail and frequency. He was always arguing with someone, and when he did, he was belligerent and unrestrained. Despite his strong religious upbringing, Yefremov was not one to turn the other cheek or seek compromise or reconciliation. Some of that, perhaps, was a quality of the times. But his autobiographical texts make it abundantly clear that he was always ready to find fault with others, to blame them for the failure of collective projects and for frictions and problems in public and personal relations between him and them. Paradoxically, a man who was so intimately involved in very many of the most significant collective political, cultural, and entrepreneurial projects of his times, was a highly partisan and self-centered participant with a strong sense of the categorical superiority of his own views on a given matter.

This pugnacity was not limited to the public sphere. In his published diary from 18951896, for example, a nineteen-year-old Yefremov, still a student at the Kyiv theological seminary, recounts a trip home to his parental home during the summer vacation of 1895 . He would rather not be going, he says, but he's still young enough to feel the need to behave like a dutiful son and come home while school's out. It doesn't help that he lives with his older brother, who is the rector of the seminary, thus adding more pressure to uphold family ties. But there's a problem. Serhii is in reasonably good relations with his parents, but his sister, Paraskeva, has recently married and the young couple, who live in Shostakove, a village only a short distance from the Yefremov home in Palchyk, have had a major argument with the senior Yefremov, Rev. Oleksandr, and his wife. The two couples no longer speak to each other. The animosity is so high that the elder couple did not even attend the funeral of their grandchild, Paraska's first child that died shortly after birth. Tensions are very high, and Serhii knows he will be expected to side with his parents against his sister. But he does nothing of the sort. Three days after his arrival at his family home, he decamps for two days to Shostakove, dramatically voting with his feet in the matter of the family squabble. He counsels and hopes for reconciliation, but ends up enduring accusations of betrayal and spends at least three of his seven weeks at home away from the family hearth, in the home of his married brother or at Paraska's. ${ }^{1}$ Serhii may have succumbed to a feeling of family loyalty or duty to come home, but he certainly feels no restraint about getting involved in someone else's argument and even taking sides against his own parents.

This minor episode has a further depth that is not at first apparent. In his diary, Serhii Yefremov never explains the cause of the argument between his parents and Paraska's family, except to suggest it was specifically with her husband. Perhaps the cause was explained in earlier volumes of his diary that he destroyed in the face of police problems. But one way or another, Serhii had a very personal stake in this family squabble that the other participants did not know about because he kept it secret from them. Shortly before this time, Serhii had fallen in love with Onysia Durdukivska, a priest's daughter. Indeed, from this point forward, when he wasn't in prison, Serhii lived the rest of his life with her. But Onysia was the sister of Ivan Durdukivskyi, the man Paraska had married and with whom the senior Yefremovs were bickering. As children 4.02.1896) [Diary, 1.01.1895-4.02.1896]; Pro dni mynuli (Spohady) (1876-1907) [About Past Days: Memoirs, 1876-1907], ed. Ihor Hyrych (Kyiv: Tempora, 2011), 117-31. 
of Orthodox clergymen, Onysia and Serhii, whether by personal choice or through deference to convention, were bound by a strict version of religious rules governing family relations and marriage. In accordance with the affinity incest taboo, since their siblings were married, they were relatives (affines) and thus could not be married. Serhii rants about the injustice of this taboo in his diary, but he apparently never found any way to subvert it. In taking the side of his sister and brother-in-law against his parents, Serhii was literally siding with those whose marriage prevented his own. Perhaps it was the symbolic value of his clergyman father as the moral authority enforcing the taboo that contributed to Serhii's anger. While the diary entries that recount the family argument are very vague - the substance of the argument is never revealed, for example - it is clear that the vehemence of Serhii's emotions was amplified by his personal romantic circumstances. ${ }^{2}$ Yefremov was a bellicose and disputatious man and, for better or worse, these qualities of his personality affected every aspect of his public and private activities.

Perhaps the best known manifestation of this argumentative temperament is seen in his comments on prominent individuals in the Academy of Sciences in his diary from 1923-1929. Judging by what he says, there was hardly a decent individual in the whole academy, excepting himself, of course. Among the most prominent and memorable figures from this diary are Mykhailo Hrushevskyi, Pavlo Tutkovskyi (Tutkivskyi for Yefremov) and Ahatanhel Krymskyi. The historian Mykhailo Hrushevskyi is the evil genius of Yefremov's later diaries. According to Yefremov, he is all but the epicentre and mastermind of all villainy in the All-Ukrainian Academy of Sciences (VUAN), a megalomaniac bent on advancing his own interests, a nepotist promoting his brother and daughter. He is continually scheming, launching intrigues, writing denunciations and otherwise undermining the smooth functioning of the Academy. Pavlo Tutkovskyi, the noted geologist and geographer, is given a similar characterization. He too is hell bent on expanding his own institute in the Academy at the cost of all others and of good sense and good order. Ahatanhel Krymskyi is somewhat less villainous, but still seen as a foolish and essentially pitiful and naive seksot. ${ }^{3}$ Yefremov's response to this villainy is not that of a passive victim. He is not an indecisive Hamlet, nor a Cicero, wondering how long patience must endure Catiline's actions. ${ }^{4}$ Time and again he rises to the challenge, creating intrigues that will embarrass and counteract Hrushevskyi at Academy meetings or with the Party bosses in Kharkiv. But what is most characteristic is a tendency to interpret any event or expression from a radically partisan perspective. A typical diatribe occurs in a brief description of Oles Dosvitnii in the entry for

2 This emotional response to the affinity incest taboo that prevented his marriage may have also contributed to Yefremov's relationship to Ivan Nechui-Levytskyi, who included a fictional account of a similar situation between siblings in his 1902 novel, Neodnakovymy stezhkamy. The taboo itself is somewhat obscure and not encountered in historical records. Thus, it is possible that NechuiLevytskyi is fictionalizing a situation that came to his attention through his acquaintance with Yefremov.

3 On Krymskyi, see Serhii Yefremov, Shchodennyky, 1923-1929 [Diaries, 1923-1929], ed. O. Putro et al. (Kyiv: Hazeta Rada, 1997), 236 (entry of May 16, 1925).

4 Quo usque tandem abutere, Catilina, patientia nostra? When, O Catiline, do you mean to cease abusing our patience? First Catiline oration. 
26 February, $1925 \cdot{ }^{5}$ Yefremov accuses Dosvitnii, who had fled to the USA to avoid execution in the tsarist army, of absconding with funds destined for the Central Rada, by deliberately taking so long to travel from San Francisco to Ukraine via Japan that by the time he arrived the Central Rada no longer existed. Not only is the whole story more than a little dubious, but the logic of the accusation is impeccably self-serving. The fault, of course, lies not with the Central Rada, which couldn't stay in power for more than a few months, but with the messenger who didn't reach it in time before it ceased to exist.

My point here is not to argue that Yefremov was a malicious gossip while Hrushevskyi, Tutkovskyi, Krymskyi, and Dosvitnii were saintly innocent victims. The story of incessant intrigues, political posturing, and back-stabbing that Yefremov tells of the Academy of Sciences is hardly surprising in any large institution, particularly one consisting largely of alpha males with extraordinarily large egos. I have no doubt that the angry intransigence demonstrated by Yefremov was to some degree shared by the people he berates and that the actual state of daily interactions in the Academy and in other institutions was not as combative and problematical as these diary judgments suggest. Nevertheless, something important is missing. Whether on their own or in groups, all of these individuals were involved in major, important projects. But the way Yefremov tells it, there is hardly any sense of common purpose, any shared responsibility for the success of a collective enterprise that is working towards shared goals. There is hardly any word of cooperation or compromise. This is particularly jarring in light of the actual political situation. Both Yefremov and the assorted colleagues he derides were in fact working against a shared and very real enemy, the communist state apparatus, which would eventually bring them all down. In these circumstances, it would not be strange or psychologically unlikely to discover a sense of shared victimization, of sympathetic appreciation for different positions, and of a willingness to compromise on some principles to help advance a shared cause. Of course, the NKVD was actively trying to prevent such convergence and foster divisions among the Ukrainian intellectuals, and Yefremov makes it clear in his diary that he understands this. But that doesn't lead to expressions of good will and mutual understanding. In their struggle to defend Ukrainian culture and identity from the Russifying assault of the party, Ukrainian intellectuals were largely disorganized and estranged from each other. Although they likely understood that they were collectively engaged in a battle against a powerful common enemy, their mutual animosities, suspicions, and mistrust created an atmosphere that made success even less likely than it would have been otherwise. Whether it be in the Academy of Sciences or on the pages of Ukrainian literary journals, where various writers and literary groupings gleefully attacked each other with great venom and passion, among the cultural intelligentsia there was little room for common purpose and accommodation in the 1920s, when Ukrainian culture and identity was permitted a limited development.

During the revolution itself, something similar was at play, although the level of cooperation was perhaps somewhat higher. Yefremov occasionally recalls events and personalities from that time in his diary from the 1920s, but there is no systematic description. He left no personal writing from 1917-1918, although he did produce a great deal of journalism at that time, which left no doubt about the difficulties of finding compromise among the various competing political 
interests and personalities. For example, in the days immediately before the proclamation of Ukrainian independence in the Fourth Universal on 9th/22nd January 1918, Yefremov was publicly arguing against independence, ${ }^{6}$ although he did vote for it in the Rada. His understanding of the political climate of the times is best gleaned from the later chapters of his memoirs, Pro dni mynuli, where he recounts his activities in the years 1905-1907. Since he wrote these memoirs in 1920-1921, before his amnesty, when he was living on the lam in Kyiv, they actually reflect his thinking after the events of the revolution. Characteristically, he focuses on the bickering between the various Ukrainian political parties and the infighting within them. The divided loyalties, ideological intransigence, and fractious disposition of the various Ukrainian political factions was a general quality of the Ukrainian Revolution, which even saw the two aligned Ukrainian governments signing treaties with each other's enemies.

While Yefremov was certainly quarrelsome and fractious, he was, ironically, also a team player, an activist focused on social and political accomplishments. Unlike the elder figures of the previous generation - for example, the members of the Old Hromada, whom he constantly criticized for their exclusively cultural rather than political interests-Yefremov sought to achieve tangible social and political change. This interest in social issues, his choice of political activism over literary fiction is a reflection of a larger shift in the spirit of the Ukrainian national awakening and indeed in revolutionary activity of all kinds in the Russian Empire at the beginning of the twentieth century. Yefremov makes this very explicit in his memoirs. Whereas the earlier generation of Ukrainian activists had largely focused on matters of cultural identity and had limited their activities to publicizing and promoting this identity, Yefremov and many other younger activists believed that these methods and goals were inadequate. In his memoirs and diary he makes frequent disparaging remarks about those Ukrainophile activists, particularly in the Hromada, who were unwilling to upgrade their goals and their methods to meet the needs and the possibilities of a new era. Specifically, Yefremov saw the need to move from a cultural to a political approach to Ukrainian activism. The first and most important step in this new approach was the creation of institutions. Their creation would transform the Ukrainian movement from a private endeavor that relied on the selfless altruism of individual activists to a social program rooted in public and private institutions. Yefremov understood the usefulness of creating facts on the ground, so to speak, rather than promoting ideals. To a large extent, his entire life as a Ukrainian activist consisted of such institution-building activities. His creation of the Vik publishing house was such a venture, as was his participation in the first Ukrainian newspaper in the Russian Empire, Hromadska dumka, and its successor Rada, where he was one of the principal contributors. And of course, his role in the Central Rada, the first modern government of an independent Ukraine, was also a manifestation of this predilection for institution building, as was also his participation in the All-Ukrainian Academy of Sciences.

Throughout his various endeavors, however, Yefremov displays a strong inclination to focus on two of his innate core values, the word and the nation. Even in purely political circumstances,

6 Oleksandr Zinchenko, "Nezalezhnist No 1: Koly Hrushevskyi ii oholosyv, chomu Vynnychenko sumnivavsia, a Yefremov buv proty [Independence No. 1: When Hrushevskyi Announced it, Why Vynnychenko Had Doubts, and Why Yefremov was Against it]," Ukrainska pravda, January 26, 2015, accessed March 3, 2017, http://www.istpravda.com.ua/articles/2015/o1/26/14696o/. 
Yefremov was often focused on language and identity. Much of his earliest political activity was directed at overturning the restrictions on Ukrainian promulgated by the Ems Ukaz. But his passion for national culture found its greatest expression in the attention he gave literature. As a publisher, as a publicist, and as a scholar, Yefremov was always launching plans for yet another literary project. The Vik publishing house, for example, was not just an institution itself. Its goal was to turn Ukrainian literature into a public institution. The anthology that was its first project was meant to project the illusion of a vibrant literary landscape, an existing and immutable fact rather than a struggle toward aspirational goals. The best evidence of its success was found in the angry complaints of all the authors, mostly modernists, whom Yefremov had left out of the anthology. Everyone understood that the collection represented a cultural pantheon, a material embodiment of the state of Ukrainian literary life, and no one wanted to be left out, not even those who knew that Yefremov did not particularly care for their writing. A similar idea informed much of his literary criticism. Yefremov's overriding goal was always to demonstrate that such a literature existed, that it reflected the national will, and that it followed a pattern determined by its own internal dynamics. These goals are most particularly apparent in his two major accomplishments as a literary scholar. The first is his History of Ukrainian Literature first published in 1911 and then revised and re-issued in subsequent years. The second is the sequence of literary biographies (Kotsiubynskyi, Karpenko-Karyi, Nechui-Levytskyi, Myrnyi) that he produced in the 1920s. While all these works are best known today for laying out a peculiar, populist vision of the role of literature in Ukrainian society, they were, in their own time, tangible monuments to the existence of Ukrainian literature.

Yefremov was, throughout his life, a builder, a doer, a creator of institutional facts on the ground. His literary criticism is a projection of his understanding of the need to produce manifest symbols, palpable works, public organizations and institutions. One of the great ironies of his life, then, lies in the fact that when the Soviet authorities finally decided to attack him and accuse him of actually doing something, they had to invent an institution whose creation they could charge him with. The ones he had already created could not be turned against him.

But what could and would be turned against him was his ideology. The key issue here is the relationship, in Yefremov's personal worldview, between culture, specifically literature, on the one hand, and social and political activism on the other. This aspect of his ideology is particularly highlighted in his memoirs and diary, which show how it gets reinforced through biographical experiences. From today's vantage point, Yefremov is best known as a literary figure. Indeed, this was his own goal early in life. From his youthful days as a pupil in the Orthodox school in Uman, Yefremov dreams of being a writer (or at least so he tells us in his memoirs 30 years later). In his years at the Seminary in Kyiv, Yefremov is trying his hand at writing fiction and in later years he will actually have some success in getting published. But in the diary entries from 1895 where he discusses the reading group that seminarians have formed, he pays more attention to the infighting in the group than to what they read. Who has paid their dues, who determines what is subscribed and read, who gets to keep the material for how long and in what order. This in not just the angry Yefremov ever ready to pick an argument with someone, this is also a strong indication of the nature of his concerns. Even when it comes to literature, justice is at least a parallel consideration. It's not that Yefremov does not express an interest in the aesthetic virtues and intellectual matter of literary works in his diary, but his innate concern for fair play seems 
to take precedence over other considerations. He spends more time describing how the various reading clubs were formed, organized, and governed than he does in analyzing the literary works he consumes. But there is one great exception to this general principle: theatre. Yefremov was a great lover of theatre and his reactions to various performances are a frequent element of his biographical writing. Yet here too, his attention is not really focused on the content of the plays (which was, admittedly, not very substantial when we are speaking of the pre-revolutionary popular ethnographic theatre), but on the actors and their ability to affect the audience with their skill. It's the effectiveness of the spectacle, its ability to arouse sentiment, that he consistently puts at the center of his judgment. That's why he will later criticize Kurbas's Berezil Theatre productions and compare them unfavorably to Starytskyi's traditional approach.

Yefremov's focus on justice and fair play, particularly as they are applied to social questions is evident in a number of emblematic biographical events that he recounts in his diary and memoirs. As a student in Kyiv's seminary, Yefremov was the recipient of a very old-fashioned philological education. In his accounts of this institution, Yefremov is, like many seminarians who were not interested in a religious vocation, quite blunt in his appraisal of the low intellectual quality of instruction, although he does occasionally mention an instructor who was intelligent and conscientious. Unlike other seminarians, Serhii Yefremov endured the additional burden of being under the watchful eye of his very conservative older brother, who was for a time the rector of the Academy and went on to become a bishop. Although this relationship sometimes worked in his favor by protecting him from punishment, on the whole he found the seminary and his brother's attention stifling, oppressive, and useless. So, eventually, he switched from the Academy to Kyiv University, where he entered the faculty of law and earned a degree as a lawyer. But why would a budding writer study law rather than philology or history? The answer lies, of course, in that tension that characterized Yefremov's thinking. His interest in literature was abstract. His interest in social justice was concrete. A degree in law would put him on a path that more clearly led in the latter direction. As it turned out, Yefremov never worked as a lawyer and later conceded that his decision to study law was impractical and largely useless. But it did put him in the midst of various student political groups at the university while he was there.

Another biographical episode that illustrates his commitment to social justice concerns his conscription into the tsarist army. For reasons he does not entirely clarify, Yefremov ignored his obligation for military service. He was a man with a pulmonary health issue that should have exempted him from conscription a priori, as it eventually did after the fact, but he did not pursue this. As a university graduate, he was entitled to service at a higher rank, but this too he did not pursue. So out of the blue, more or less, he gets a notice to appear for service, which he dutifully follows. The story that comes out makes for excellent reading and involves a range of anecdotal material of all sorts, including a completely unexpected visit to Ahatanhel Krymskyi at his home in Zvenyhorodka. But the major point of Yefremov's story is to underscore the enormous injustice endured by conscripts in the army, a fate he mostly avoids and observes at a proximate distance because as a university graduate he is treated differently, despite the fact that he did not take advantage of the official route by which university graduates avoid the horrors of rank-and-file service. In the final analysis, Yefremov tells a story in which he is not really a victim, but rather a witness — since he himself was living in somewhat privileged 
circumstances and exposed to it for only a few months - of the abuse inflicted on conscripts in the Russian army. An experience that might have been framed as a testimony of personal suffering is instead treated as an indictment of social problems. Yefremov will later do something similar when he describes his first experience in prison. His account will again emphasize the suffering of the other inmates, particularly of the simple people who don't have the education and the social status that he enjoys.

Yefremov's preoccupation with injustice, particularly to the lower classes, is important, but certainly not unusual for the times. No doubt most decent people in the Russian Empire at the time shared some of this sentiment. Indeed, the revolutionary events in the Russian Empire that led to the victory of the Bolshevik communists were obviously a consequence of the prevalence of these attitudes. In this, Yefremov again exemplifies the times, if only trivially. But what marks his views as particularly relevant to the Ukrainian Revolution is his insistence on national identities. Yefremov sees everything through the prism of nationality. The greatest injustice, in his view, is not merely social, but national and social. This is how Yefremov understands the position of Ukrainians in the Russian Empire, as a group that is oppressed both socially and nationally. His entire life was dedicated to overcoming this oppression but not through mere advocacy - the fault he ascribes to the previous generation of cultural activists - but, as noted above, through the establishment of structures and monuments, whether social, political, or cultural, that would prevent or counteract such discrimination.

Yefremov's national perspective is evident throughout his writing and not only in connection with Ukrainians. One of the most problematical characteristics of his diaries from the 1920 is the frequency and vehemence of his negative pronouncements about Jews. These pronouncements run a wide gamut of circumstances. He frequently comments on the Jews in the communist party and characterizes them as careerists who have no particular allegiance to communist ideals and are overtly hostile to Ukrainization. He also makes frequent negative comments about the Jewish Studies section of VUAN, asserting in particular that the section has too many pseudoscholars who don't belong in the Academy. There are also frequent comments about Jewish businessmen, usually seen negatively as exploiters. And, of course, there are the relentless jokes, usually introduced with the phrase "Recent Folklore" 7 and often on an ethnic topic. There are two good examples in the diary entry from December $21,1927^{8}$ following the expulsion of Trotsky and Zinoviev and the condemnation of the Left Opposition at the 15th Party Congress in Moscow: "One group is dancing the Lezginka while the other group is singing "By the rivers of Babylon."'9 (A reference to Psalm 137). Yefremov quickly adds another joke: "One Georgian = a shoe shine boy, two Georgians = lezginka, three Georgians = the Central Committee; one Jew = a speculator, two Jews $=$ a cartel, three Jews $=$ the opposition; one Ukrainian $=$ Ukrainization, two Ukrainians = with some sausage and vodka we can avoid a quarrel (alternatively = hopak); three Ukrainians $=$ a pogrom ; one Russian $=$ a dope, two Russians $=$ two dopes, three Russians

$7 \quad$ Iz novitnoho folkloru.

8 Yefremov, Shchodennyky, 1923-1929, 565.

Odni tantsiuiut lezhynku, a druhi spivaiut "Na rekakh Vavylonskykh." 
= three dopes." ${ }^{10}$ The jokes are very characteristic of Yefremov's views, not because they express a prejudice against Georgians, Jews, and Russians but because they underscore his essentially and unabashedly ethnic view of the world around him. Yefremov sees issues in a national light. His understanding of the politics of his times is filtered through a Ukrainian-cantered prism. This does not necessarily lead to a sense of ethnic superiority and while his jokes and comments often seem to suggest an underlying anti-Semitism, it is very important to temper that impression with other passages in his diaries and memoirs where he is openly critical of anti-Semitism, particularly the lengthy description of the pogrom in Kyiv on October $17,1905 .{ }^{11}$ That pogrom, in fact, led to the appearance of the first newspaper article in Ukrainian in the Russian empire, Yefremov's “Chy bude sud?" (Will there be a trial?) in Kievskie otkliki. In his diary entry from 24 March, 1928, ${ }^{12}$ Yefremov recounts with bitterness a meeting with Olena Pchilka who chastises him for that article. Evidently, he didn't satisfy her expectations of innate Ukrainian anti-Semitism.

In his essay about Yefremov's History of Ukrainian Literature, ${ }^{13}$ Hryhorii Hrabovych justly characterizes the author's aesthetic principles as service to the people, the nation, the narod. It's not universal qualities that Yefremov looks for in literature, it's the particular, the ethnic, the national. In this, Yefremov's literary philosophy is entirely in keeping with his personal, political, and social views. His striving to bring justice and dignity to the Ukrainian nation characterized most of what he sought to accomplish in his life. And in this quality, too, he was an avatar of the Ukrainian Revolution, which differed from the general revolution in the empire not in its localization, but in the fact that it introduced a new principle, a new goal into revolutionary efforts. The Ukrainian Revolution was characterized precisely by the national question. What made Ukrainian revolutionary events distinct was the introduction of a new dimension, the national one, with which all the other dimensions needed to interact and coexist. The various parties, governments, and armies all had to account for the needs, the tastes, and the desires of the Ukrainian nation, of the narod. Even the victorious Bolsheviks, who didn't shirk from open military invasion of the country, nevertheless made concessions to the national feelings of Ukrainians, understood mostly as a cultural entity. Eventually, both Yefremov and these concessions to Ukrainian aspirations were liquidated. The two were practically synonymous.

In the reflection of the disunity that characterized Ukrainian organizations, in the understanding of the need to create institutional pillars for their cause, and in the explicit concentration on fairness and justice for the Ukrainian nation Yefremov's legacy marks him as an important witness of the events of the Ukrainian Revolution and an embodiment of its

10 Odyn hruzyn — chystylshchyk chobit; dva hruzyny — lezghynka; try hruzyny — TsK. Odyn zhyd — spekuliant; dva zhyda — trest; try zhyda — opozytsiia. Odyn ukrainets — ukrainizatsiia; dva ukraintsia — yak kovbasa ta charka, to mynetsia i svarka (shche kazhut hopak); try ukraintsia — pohrom. Odyn russkii — durak; dva russkykh — dva duraka; try russkykh — try duraka.

11 Yefremov, Shchodennyk (1.01.1895-4.02.1896), 597-6o6.

12 Yefremov, Shchodennyky, 1923-1929, 6о3.

13 Hryhorii Hrabovych, "Serhii Yefremov yak istoryk ukrainskoho pysmenstva [Serhii Yefremov as a Historian of Ukrainian Literature]," Suchasnist 10 (1976): 52-61 (rpt. in Do istorii ukrainskoi literatury: Doslidzhennia, ese, polemika (Kyiv: Krytyka, 1997), 418-31.) 
problems and paradoxes. In his writings, in his politics, in his personal activities, Yefremov was an instrument and an embodiment of the forces that shaped revolutionary events in Ukraine one hundred years ago. He was the epitome of his times.

\section{Bibliography}

Hrabovych, Hryhorii. "Serhii Yefremov yak istoryk ukrainskoho pysmenstva [Serhii Yefremov as a Historian of Ukrainian Literature]." Suchasnist 10 (1976): 52-61.

Yevhen Chykalenko, Serhii Yefremov: Lystuvannia, 1903-1928 roky [Yevhen Chykalenko, Serhii Yefremov: Correspondence, 1903-1928]. Edited by Iryna Starovoitenko. Kyiv: Tempora, 2010.

Yefremov, Serhii. Istoriia ukrainskoho pysmenstva [The History of Ukrainian Literature]. Kyiv: Femina, 1995 .

Yefremov, Serhii. Literaturno-krytychni statti [Critical Essays on Literature]. Edited by Eleonora Solovei. Kyiv: Dnipro, 1993.

Yefremov, Serhii. Publitsystyka revoliutsinoi doby (1917-1920 rr.) [The Publicist Articles of the Revolutionary Era, 1917-1920]. Edited by Vladyslav Verstiuk et al. Kyiv: Dukh i litera, 2014.

Yefremov, Serhii. Shchodennyk (1.01.1895-4.02.1896) [Diary, 1.01.1895-4.02.1896]; Pro dni mynuli (Spohady) (1876-1907) [About Past Days: Memoirs, 1876-1907], edited by Ihor Hyrych. Kyiv: Tempora, 2011.

Yefremov, Serhii. Shchodennyky, 1923-1929 [Diaries, 1923-1929]. Edited by O. Putro et al. Kyiv: Hazeta Rada, 1997.

Yefremov, Serhii. Vybrane: Statti, naukovi rozvidky, monohrafii [Selected Works: Articles, Scholarly Enquiries, Monographs]. Edited by Eleonora Solovei. Kyiv: Naukova Dumka, 2002.

Yefremov, Serhii. Ausgewählte Werke. Heidelberg: Carl Winter Universitätsverlag, 1989.

Yefremov, Serhii. Za rik 1921-i. Pid obukhom: Bilshovykyv Kyievi [About the Year 1921: Under the Axe. The Bolsheviks in Kyiv]. Kyiv: Orii, 1993.

Zinchenko, Oleksandr. "Nezalezhnist $N^{50}$ 1: Koly Hrushevskyi ii oholosyv, chomu Vynnychenko sumnivavsia, a Yefremov buv proty [Independence No. 1: When Hrushevskyi Announced it, Why Vynnychenko Had Doubts, and Why Yefremov was Against it]." Ukrainska pravda, January 26, 2015. Accessed March 3, 2017. http://www.istpravda.com.ua/articles/2015/o1/26/ $146960 /$.

Maxim Tarnawsky is a professor in the Department of Slavic Languages and Literatures at the University of Toronto. His most recent work is a monograph on Ivan Nechui-Levytskyi entitled The All-Encompassing Eye of Ukraine: Ivan Nechui-Levyts'kyi's Realist Prose (Toronto: University of Toronto Press, 2015), translated into Ukrainian as Nechuvanyi Nechui (Kyiv: Laurus, 2016). He is currently working on a monograph about Ivan Franko's late prose. 